\title{
UPAYA MENINGKATKAN PRESTASI BELAJAR PKn DENGAN PEMBERIAN FLASH BACK PADA SISWA KELAS VIII c SMP NEGERI 1 SEKARAN KABUPATEN LAMONGAN TAHUN PELAJARAN 2017/2018
}

\author{
Supriyono \\ SMP Negeri 1 Sekaran, Lamongan
}

\begin{tabular}{l}
\hline INFO ARTIKEL \\
\hline Riwayat Artikel: \\
Diterima: 4-01-2019 \\
Disetujui: 7-01-2019 \\
\end{tabular}

Kata kunci:

Belajar PKn

Pemberian Flash Back

\footnotetext{
Alamat Korespondensi:

Supriyono

Guru SMPN 1 Sekaran, Lamongan

SMPN 1 Sekaran, Kabupaten Lamongan, Jawa Timur

E-mail: supriyonopriyono81@gmail.com
}

\begin{abstract}
The purpose of research that will be obtained is : (a) to reveal the effect of learning by giving flash back to learning result of Civics (PKn). (b) to reveal learning by giving flash back of wefivation to learn Civics (PKn). This research used action research three round. Each round consist Of four stages :design activity and observation,reflection, and revision. The target of this research is the students of VIIIc class of junior high school in the form of the result of formative test,observation sheet of teaching and learning activities. Form the analysis result got that student Achievemeut have improved from cycle I to cycle III , cycle I $(71,42 \%)$, cycle II $(80,95 \%)$, cycle III $(90,47 \%)$. The conclusion from the research is the teaching by giving flash back can positively influence to the achievement and motivation in learning of VIIIc of SMP Negeri 1 Sekaran, and this learning model can use as one of the alternative of learning and teaching Civics (PKn).

Abstrak: Tujuan penelitian yang hendak diperoleh adalah: (a) Untuk mengungkap pengaruh pembelajaran dengan pemberian Flash Back terhadap hasil belajar PKn, (b) Untuk mengungkapkan pembelajaran dengan pemberian Flash Back terhadap motivasi belajar PKn. Penelitian ini menggunakan penelitian tindakan (action research) sebanyak tiga putaran. Setiap putaran terdiri dari empat tahap yaitu: rancangan, kegiatan dan pengamatan, refleksi, dan revisi. Sasaran penelitian ini adalah siswa Kelas VIII c SMP Negeri 1 Sekaran Data yang diperoleh berupa hasil tes formatif, lembar observasi kegiatan belajar mengajar. Dari hasil analisis didapatkan bahwa prestasi belajar siswa mengalami peningkatan dari siklus I sampai siklus III yaitu, siklus I $(71,42 \%)$, siklus II $(80,95 \%)$, siklus III $(90,47 \%)$. Kesimpulan dari penelitian ini adalah pengajaran dengan pemberian Flash Back dapat berpengaruh positif terhadap prestasi dan motivasi belajar siswa Kelas VIII c SMP Negeri 1 Sekaran., serta model pembelajaran ini dapat digunakan sebagai salah satu alternative pembelajaran PKn.
\end{abstract}


Prestasi belajar salah satu alat pengukur berhasil tidaknya proses belajar yang dilakukan anak. Jika prestasi belajar yang dicapai anak rendah berarti proses belajar yang dilakukan anak kurang berhasil. Sebaliknya bila prestasi belajar yang dicapai anak tinggi bisa dikatakan bahwa anak mencapai keberhasilan dalam belajarnya.

Kualitas pembelajaran ditentukan oleh interaksi komponen-komponen dalam sistemnya. Yaitu tujuan, bahan ajar (materi), anak didik, sarana, media, metode, partisipasi masyarakat, performance sekolah, dan evaluasi pembelajaran (Moh. Shochib, 1998). Optimalisasi komponen ini, menentukan kualitas (proses dan produk) pembelajaran.

Upaya yang dapat dilakukan oleh pendidik adalah melakukan analisis tentang karakteristik setiap komponen dan mesinkronisasikan sehingga ditemukan konsistensi dan keserasian diantaranya untuk tercapainya tujuan pembelajaran. Karena pembelajaran mulai dari perencanaan, pelaksanaan dan evaluasinya senantiasa merujuk pada tujuan yang diharapkan untuk dikuasai atau dimiliki oleh anak didik baik instructional effect sesuai dengan tujuan yang dirancang maupun nutrient effect (dampak pengiring) (Moch. Shochib: 1999).

Realisasi pencapaian tujuan tersebut, terdapat kegiatan interaksi belajar mengajar terutama yang terjadi di kelas. Dengan demikian, kegiatannya adalah bagaimana terjadi hubungan antara guru/bahan ajar yang didesain dan dengan anak didik. Interaksi ini merupakan proses komunikasi penyampaian pesan pembelajaran. Hal ini sejalan dengan yang dikemukakan Arief. S. Sadiman yang menyatakan proses belajar mengajar pada hakekatnya adalah proses interaksi yaitu proses penyampaian pesan melalui saluran media/teknik/metode ke penerima pesan (Arief. S. Sadiman, dkk, 1996:13).

Kualitas pendidikan, sebagai salah satu pilar pengembangan sumber daya manusia yang bermakna, sangat penting bagi pembangunan nasional. Bahkan dapat dikatakan masa depan bangsa tergantung pada keberadaan pendidikan yang berkualitas yang berlangsung di masa kini. Pendidikan yang berkualitas hanya akan muncul dari sekolah yang berkualitas. Oleh sebab itu, upaya peningkatan kualitas sekolah merupakan titik sentral upaya menciptakan pendidikan yang berkualitas demi terciptanya tenaga kerja yang berkualitas pula. Dengan kata lain upaya peningkatan kualitas sekolah adalah merupakan tindakan yang tidak pernah terhenti, kapanpun, dimanapun dan dalam kondisi apapun.

Dalam upaya peningkatan kualitas sekolah, tenaga kependidikan yang meliputi, tenaga pendidik, pengelola satuan pendidikan, penilik, pengawas, peneliti, teknik sumber belajar, sangat diharapkan berperan sebagaimana mestinya dan sebagai tenaga kependidikan yang berkualitas. Tenaga pendidik/guru yang berkualitas adalah tenaga pendidik/guru yang sanggup, dan terampil dalam melaksanakan tugasnya.

Tugas utama guru adalah bertanggung jawab membantu anak didik dalam hal belajar. Dalam proses belajar mengajar, gurulah yang menyampaikan pelajaran, memecahkan masalah-masalah yang terjadi dalam kelas, membuat evaluasi belajar siswa, baik sebelum, sedang maupun sesudah pelajaran berlangsung (Combs, 1984: 1113). Untuk memainkan peranan dan melaksanakan tugas-tugas itu, seorang guru diharapkan memiliki kemampuan profesional yang tinggi. Dalam hubungan ini maka untuk mengenal siswa-siswanya dengan baik, guru perlu memiliki kemampuan untuk melakukan diagnosis serta mengenal dengan baik cara-cara yang paling efektif untuk membantu siswa tumbuh sesuai dengan potensinya masing-masing. Proses pembelajaran yang dilakukan guru memang dibedakan keluasan cakupannya, tetapi dalam konteks kegiatan belajar mengajar mempunyai tugas yang sama. Maka tugas mengajar bukan hanya sekedar menuangkan bahan pelajaran, tetapi teaching is primarily and always the stimulation of learner (Wetherington, 1986: 131-136), dan mengajar tidak hanya dapat dinilai dengan hasil penguasaan mata pelajaran, tetapi yang terpenting adalah perkembangan pribadi anak, sekalipun mempelajari pelajaran yang baik, akan memberikan pengalaman membangkitkan bermacam-macam sifat, sikap dan kesanggupan yang konstruktif.

Dengan tercapainya tujuan dan kualitas pembelajaran, maka dikatakan bahwa guru telah berhasil dalam mengajar. Keberhasilan kegiatan belajar mengajar tentu saja diketahui setelah diadakan evaluasi dengan berbagai faktor yang sesuai dengan rumusan beberapa tujuan pembelajaran. Sejauh mana tingkat keberhasilan belajar mengajar, dapat dilihat dari daya serap anak didik dan presentase keberhasilan anak didik dalam mencapai tujuan pembelajaran khusus. Jika hanya tujuh puluh lima persen atau lebih dari jumlah anak didik yang mengikuti proses belajar mengajar mencapai taraf keberhasilan kurang (dibawah taraf minimal), maka proses belajar mengajar berikutnya hendaknya ditinjau kembali.

Setiap akan mengajar, guru perlu membuat persiapan mengajar dalam rangka melaksanakan sebagian dari rencana bulanan dan rencana tahunan. Dalam persiapan itu sudah terkandung tentang, tujuan mengajar, pokok yang 
akan diajarkan, metode mengajar, bahan pelajaran, alat peraga dan teknik evaluasi yang digunakan. Karena itu setiap guru harus memahami benar tentang tujuan mengajar, secara khusus memilih dan menentukan metode mengajar sesuai dengan tujuan yang hendak dicapai, cara memilih, menentukan dan menggunakan alat peraga, cara membuat tes dan menggunakannya, dan pengetahuan tentang alat-alat evaluasi.

Sementara itu teknologi pembelajaran adalah salah satu dari aspek tersebut yang cenderung diabaikan oleh beberapa pelaku pendidikan, terutama bagi mereka yang menganggap bahwa sumber daya manusia pendidikan, sarana dan prasarana pendidikanlah yang terpenting. Padahal kalau dikaji lebihlanjut, setiap pembelajaran pada semua tingkat pendidikan baik formal maupun non formal apalagi tingkat Sekolah lanjutan, haruslah berpusat pada kebutuhan perkembangan anak sebagai calon individu yang unik, sebagai makhluk sosial, dan sebagai calon manusia seutuhnya.

Hal tersebut dapat dicapai apabila dalam aktivitas belajar mengajar, guru senantiasa memanfaatkan teknologi pembelajaran yang mengacu pada pembelajaran dengan pemberian Flash Back dalam penyampaian materi dan mudah diserap peserta didik atau siswa berbeda. Khususnya dalam pembelajaran PKn, agar siswa dapat memahami materi yang disampaikan guru dengan baik, maka proses pembelajaran dengan pemberian Flash Back, guru akan memulai membuka pelajaran dengan menyampaikan kata kunci, tujuan yang ingin dicapai, baru memaparkan isi dan diakhiri dengan memberikan soal-soal kepada siswa. Dari latar belakang masalah tersebut, maka peneliti merasa terdorong untuk melihat pengaruh pembelajaran dengan pemberian Flash Back terhadap prestasi belajar siswa dengan mengambil judul "Upaya Meningkatkan Prestasi Belajar PKn Dengan Menerapkan Metode Pemberian Flash Back Pada Siswa Kelas VIIIc SMP Negeri 1 Sekaran Tahun Pelajaran 2017/2018.

\section{METODE}

Penelitian ini merupakan penelitian tindakan (action research), karena penelitian dilakukan untuk memecahkan masalah pembelajaran di kelas. Penelitian ini juga termasuk penelitian deskriptif, sebab menggambarkan bagaimana suatu teknik pembelajaran diterapkan dan bagaimana hasil yang diinginkan dapat dicapai.

Menurut Oja dan Sumarjan (dalam Titik Sugiarti, 1997;8) mengelompokkan penelitian tindakan menjadi empat macam yaitu (a) guru bertindak sebagai peneliti, (b) penelitian tindakan kolaboratif, (c) Simultan terintegrasi, dan (d) administrasi sosial eksperimental.

Dalam penelitian tindakan ini menggunakan bentuk penelitian kolaboratif dengan guru bidang studi dan di dalam proses belajar mengajar di kelas yang bertindak sebagai pengajar adalah guru bidang studi sedangkan peneliti bertindak sebagai pengamat, penanggung jawab penuh penelitian tindakan adalah pengamat (peneliti). Tujuan utama dari penelitian tindakan ini adalah meningkatkan hasil pembelajaran di kelas dimana peneliti secara penuh terlibat dalam penelitian mulai dari perencanaan, tindakan, pengamatan dan refleksi.

\section{HASIL}

Data yang diperoleh berupa hasil uji coba item butir soal, data observasi berupa pengamatan pengolahan pembelajaran dengan menggunakan media charta, model dan LKS dan pengamatan aktivitas siswa dan guru pada akhir pembelajaran, dan data tes formatif siswa pada setiap siklus.

Data hasil uji coba item butir soal digunakan untuk mendapatkan tes yang betul-betul mewakili apa yang diinginkan. Data ini selanjutnya dianalisis tingkat validitas, reliabilitas, taraf kesukaran, dan daya pembeda.

Data lembar observasi diambil dari dua pengamatan yaitu data pengamatan pengolahan pembelajaran dengan menggunakan media charta, model dan LKS yang digunakan untuk mengetahui pengaruh penerapan belajar dengan media charta, model dan LKS dalam peningkatan prestasi.

Data tes formatif untuk mengetahui peningkatan prestasi belajar siswa setelah diterapkan pembelajaran dengan memberikan Flash Back. 


\section{PEMBAHASAN}

Siklus I

a. Tahap perencanaan

Pada tahap ini penelitian mempersiapkan perangkat pembelajaran yang terdiri dari rencana pelajaran 1, LKS 1, soal tes formatif 1 dan alat-alat pengajaran yang mendukung. Selain itu juga mempersiapkan lembar observasi pengolahan pembelajaran dengan pemberian Flash Back.

b. Tahap Kegiatan dan Pelaksanaan

Pelaksanaan kegiatan belajar mengajar untuk siklus I dilaksanakan pada tanggal 4 September 2017 di kelas $8 \mathrm{c}$ dengan jumlah siswa 21 siswa. Dalam hal ini peneliti bertindak sebagai pengamat dengan dibantu oleh seorang guru, sedangkan yang bertindak sebagai pengajar adalah guru bidang studi PKn. Adapun proses belajar mengajar mengacu pada rencana pelajaran yang telah dipersiapkan. Pengamatan (observasi) dilaksanakan bersamaan dengan pelaksanaan belajar mengajar.

Pada akhir proses belajar mengajar siswa diberi tes formatif I dengan tujuan untuk mengetahui tingkat keberhasilan siswa dalam proses belajar mengajar yang telah dilakukan. Adapun data hasil penelitian pada siklus I adalah sebagai berikut:

Tabel 1 Rekapitulasi Hasil Tes Formatif Siswa pada Siklus I

\begin{tabular}{|c|l|c|}
\hline No & \multicolumn{1}{|c|}{ Uraian } & Hasil siklus I \\
\hline 1 & Nilai rata-rata tes formatif & 70,47 \\
\hline 2 & Jumlah siswa yang tuntas belajar & $` 15$ \\
\hline 3 & Persentase ketuntasan belajar & 71,42 \\
\hline
\end{tabular}

Dari tabel di atas dapat dijelaskan bahwa dengan menerapkan pembelajaran dengan memberikan balikan pada materi pelajaran diperoleh nilai rata-rata prestasi belajar siswa adalah 70,47 dan ketuntasan belajar mencapai 71,42\% atau ada 15 siswa dari 21siswa sudah tuntas belajar. Hasil tersebut menunjukkan bahwa pada siklus pertama secara klasikal siswa belum tuntas belajar, karena siswa yang memperoleh nilai $\geq 65$ hanya sebesar 71,42\% lebih kecil dari presentase ketuntasan yang dikehendaki yaitu sebesar $85 \%$. Hal ini disebabkan karena siswa banyak yang merasa asing dan bingung dengan metode pembelajaran yang dilakukan oleh guru.

2. Siklus II

a. Tahap Perencanaan

Pada tahap ini peneliti mempersiapkan perangkat pembelajaran yang terdiri dari rencana pelajaran 2, soal tes formatif II dan alat-alat pengajaran yang mendukung.

b. Tahap kegiatan dan pelaksanaan

Pelaksanaan kegiatan belajar mengajar untuk siklus II dilaksanakan pada tanggal 11 September 2017 di kelas 8c dengan jumlah 21 siswa. Dalam hal ini peneliti bertindak sebagai pengamat dengan dibantu oleh seorang guru, sedangkan yang bertindak sebagai pengajar adalah guru bidang studi PKn. Adapun proses belajar mengajar mengacu pada rencana pelajaran dengan memperhatikan revisi pada siklus I, sehingga kesalahan atau kekurangan pada siklus I tidak berulang lagi pada siklus II. Pengamatan (observasi) dilaksanakan bersamaan dengan pelaksanaan belajar mengajar.

Pada akhir proses belajar mengajar siswa diberi tes formatif I dengan tujuan untuk mengetahui tingkat keberhasilan siswa. 
KARANGAN: Jurnal Kependidikan, Pembelajaran, dan Pengembangan, Vol 01, No 01, Bln Feb, Thn 2019, Hal 31-36

Tabel 2. Rekapitulasi Hasil Tes Formatif Siswa pada Siklus II

\begin{tabular}{|c|l|c|}
\hline No & \multicolumn{1}{|c|}{ Uraian } & Hasil Siklus II \\
\hline 1 & Nilai rata-rata tes Formatif & 72,85 \\
2 & Jumlah siswa yang tuntas belajar & 17 \\
3 & Persentase ketuntasan belajar & 80,95 \\
\hline
\end{tabular}

Dari tabel di atas diperoleh nilai rata-rata prestasi belajar siswa adalah 72,85\% dan ketuntasan belajar mencapai 80,95\% atau ada 17 siswa dari 21 siswa yang sudah tuntas belajar. Hasil ini menunjukkan bahwa pada siklus II ini ketuntasan belajar secara klasikal telah mengalami peningkatan sedikit lebih baik dari siklus I. Adanya peningkatan hasil belajar siswa ini karena siswa-siswa telah mulai mengulang pelajaran yang sudah diterimanya selama ini sehingga para siswa sebagian sudah mengingat materi yang telah diajarkan oleh guru.

3. Siklus III

a. Tahap Perencanaan

Pada tahap ini peneliti mempersiapkan perangkat pembelajaran yang terdiri dari rencana pelajaran 3 , soal tes formatif 3 dan alat-alat pengajaran yang mendukung.

b. Tahap kegiatan dan pengamatan

Pelaksanaan kegiatan belajar mengajar untuk siklus III dilaksanakan pada tanggal 18 September 2017 di kelas 8c dengan jumlah siswa 21 siswa. Dalam hal ini penelitian bertindak sebagai pengamat dengan dibantu oleh seorang guru, sedangkan yang bertindak sebagai pengajar adalah guru bidang studi. Adapun proses belajar mengajar mengacu pada rencana pelajaran dengan memperhatikan revisi pada siklus II, sehingga kesalahan atau kekurangan pada siklus II tidak terulang lagi pada siklus III. Pengamatan (observasi) dilaksanakan bersamaan dengan pelaksanaan belajar mengajar.

Pada akhir proses belajar mengajar siswa dalam proses belajar mengajar yang telah dilakukan. Instrumen yang digunakan adalah tes formatif III. Adapun data hasil penelitian pada siklus III adalah sebagai berikut.

Tabel 3 Rekapitulasi Hasil Tes Formatif Siswa pada Siklus III

\begin{tabular}{|c|l|c|}
\hline No & \multicolumn{1}{|c|}{ Uraian } & Hasil Siklus III \\
\hline 1 & Nilai rata-rata tes formatif & 80,47 \\
\hline 2. & Jumlah siswa yang tuntas belajar & 19 \\
\hline 3. & Persentase ketuntasan belajar & 90,47 \\
\hline
\end{tabular}

Berdasarkan tabel diatas diperoleh nilai rata-rata tes formatif sebesar 80,47 dan dari 21 siswa yang telah tuntas sebanyak 19 siswa dan 2 siswa belum mencapai ketuntasan belajar. Maka secara klasikal ketuntasan belajar yang telah tercapai sebelum 90,47\% (termasuk kategori tuntas). Hasil pada siklus III ini mengalami peningkatan lebih dari siklus II. Adanya peningkatan hasil belajar pada siklus III ini dipengaruhi oleh adanya usaha siswa untuk mempelajari kembali materi ajar yang telah disampaikan oleh guru.

\section{SIMPULAN}

Dari hasil kegiatan pelajaran yang telah dilakukan selama tiga siklus, dan berdasarkanseluruh pembahasan serta analisis yang telah dilakukan dapat disimpulkan sebagai berikut:

1. Pembelajaran dengan memberikan Flash Back pada materi pelajaran memiliki dampak positif dalam meningkatkan prestasi belajar siswa yang ditandai dengan peningkatan ketuntasan belajar siswa setiap siklus, yaitu siklus I (71,42\%), siklus II (80,95\%), Siklus III $(90,47 \%)$.

2. Penerapan pembelajaran dengan memberikan Flash Back pada materi pelajaran mempunyai pengaruh positif, yaitu dapat meningkatkan motivasi belajar siswa yang ditunjukkan dengan rata-rata jawaban siswa yang menyatakan bahwa siswa tertarik dan berminat dengan pembelajaran dengan memberikan Flash Back pada materi pelajaran sehingga mereka menjadi termotivasi untuk belajar. 
3. Penerapan pembelajaran dengan memberikan Flash Back pada materi pelajaran efektif untuk mengingatkan kembali materi ajar yang telah diterima siswa selama ini, sehingga mereka merasa siap untuk menghadapi ujian akhir yang segera akan dilaksanakan.

\section{DAFTAR RUJUKAN}

Ardana, Wayan. 1980.Beberapa Metode Statistik Untuk Keperluan Penelitian Pendidikan. Malang : Swadaya.

Arikunto, Suharsimi. 1993.Manajemen Mengajar Secara Manusiawi. Jakarta: Rieksa Cipta.

Arikunto, Suharsimi. 2001. Dasar-dasarEvaluasi Pendidikan. Jakarta: Bina Aksara.

Arikunto, Suharsimi. 1989.Penilaian Program Pendidikan. Proyek Pengembangan LPTK Depdikbud. Dirjen Dikti.

Arikunto, Suharsimi. 1998.Prosedur Penelitian Suatu Pendekatan Praktek. Jakarta: Bina Aksara.

Combs. Arthur. W. 1984. The Profesional Education of Teachers. Allin and Bacon, Inc. Boston.

Djamarah, Syaiful Bahri. 1994. Guru dan Anak Didik dalam Interaksi Edukatif. Fakultas Tarbiyah IAIN Antasasi. Banjarmasin.

Djamrah, Syaiful Bahri. 2002. Strategi Belajar Mengajar. Jakarta : Bina Aksara.

Combs. Arthur. W. 1984. Prosedur Penelitian Suatu Pendekatan Praktek. Jakarta : Bina Aksara.

Djamarah, Syaiful Bahri. 1994. Guru dan Anak Didik dalam Interaksi Edukatif. Fakultas Tarbiyah IAIN Antasasi. Banjarmasin

Djamarah, Syaiful Bahri. 2002. Strategi Belajar Mengajar. Jakarta : Rineksa Cipta. 